\title{
Intercomparison of polar ozone profiles by IASI/MetOp sounder with 2010 Concordiasi ozonesonde observations
}

\author{
J. Gazeaux ${ }^{1,2}$, C. Clerbaux ${ }^{1,3}$, M. George ${ }^{1}$, J. Hadji-Lazaro ${ }^{1}$, J. Kuttippurath ${ }^{1}$, P.-F. Coheur ${ }^{3}$, D. Hurtmans ${ }^{3}$, \\ T. Deshler ${ }^{4}$, M. Kovilakam ${ }^{4}$, P. Campbell ${ }^{4}$, V. Guidard ${ }^{5}$, F. Rabier ${ }^{5}$, and J.-N. Thépaut ${ }^{6}$ \\ ${ }^{1}$ UPMC Univ. Paris 06; Université Versailles St-Quentin; CNRS/INSU, UMR8190, LATMOS-IPSL, Paris, France \\ ${ }^{2}$ School of Civil Engineering and Geosciences, Newcastle University, Newcastle upon Tyne, UK \\ ${ }^{3}$ Spectroscopie de l'Atmosphère, Université Libre de Bruxelles, Brussels, Belgium \\ ${ }^{4}$ Department of Atmospheric Science, Wyoming University, Laramie, WY, USA \\ ${ }^{5} \mathrm{CNRM} / \mathrm{GAME}$ (Météo-France and CNRS), Toulouse, France \\ ${ }^{6}$ European Centre for Medium-Range Weather Forecasts, Reading, UK
}

Correspondence to: C. Clerbaux (cathy.clerbaux@ latmos.ipsl.fr)

Received: 25 September 2012 - Published in Atmos. Meas. Tech. Discuss.: 29 October 2012

Revised: 12 February 2013 - Accepted: 22 February 2013 - Published: 8 March 2013

\begin{abstract}
Validation of ozone profiles measured from a nadir looking satellite instrument over Antarctica is a challenging task due to differences in their vertical sensitivity with ozonesonde measurements. In this paper, ozone observations provided by the Infrared Atmospheric Sounding Interferometer (IASI) instrument onboard the polar-orbiting satellite MetOp are compared with ozone profiles collected between August and October 2010 at McMurdo Station, Antarctica, during the Concordiasi measurement campaign. The main objective of the campaign was the satellite data validation. With this aim 20 zero-pressure sounding balloons carrying ozonesondes were launched during this period when the MetOp satellite was passing above McMurdo. This makes the dataset relevant for comparison, especially because the balloons covered the entire altitude range of IASI profiles. The validation methodology and the collocation criteria vary according to the availability of global positioning system auxiliary data with each electro-chemical cell ozonesonde observation. The relative mean difference is shown to depend on the vertical range investigated. The analysis shows a good agreement in the troposphere (below $10 \mathrm{~km}$ ) and middle stratosphere $(25-40 \mathrm{~km})$, where the differences are lower than $10 \%$. However a significant positive bias of about 10 $26 \%$ is estimated in the lower stratosphere at $10-25 \mathrm{~km}$, depending on altitude. The positive bias in the $10-25 \mathrm{~km}$ range is consistent with previously reported studies comparing in situ data with thermal infrared satellite measurements. This
\end{abstract}

study allows for a better characterization of IASI-retrieved ozone over the polar region during ozone depletion/recovery processes.

\section{Introduction}

Surveying ozone distribution over Antarctica is an important task for quantifying ozone depletion over the poles (Newman et al., 2009), and to assess the efficiency of the international protocols controlling the emission of chlorine containing compounds. Stratospheric ozone is essential for ultraviolet radiation protection, which allows life to remain on earth and is closely linked to climate change and stratospheric circulation over the poles. For decades, satellites have provided valuable measurements of the composition of the atmosphere, in particular to follow the ozone chemistry in the polar stratosphere in spring (WMO, 2011).

In 2010 the Concordiasi campaign was organized at McMurdo Station (Long: $166.67^{\circ}$, Lat: $-77.85^{\circ}$ ), Antarctica (Fig. 1), by teams from France and United States, to improve knowledge and understanding of the interactions between ozone depletion, stratospheric clouds and atmospheric dynamics (Rabier et al., 2012). This campaign also aimed to provide additional information to better exploit the temperature, water vapour and ozone observations provided by the Infrared Atmospheric Sounding Interferometer 
(IASI) instrument onboard the European polar-orbiting satellite MetOp. Such information is required by atmospheric models. But due to low temperatures, which makes the radiance data provided by thermal infrared instruments noisy, soundings above ice sheets are difficult (e.g. Vincensini et al., 2012; Pommier et al., 2012; Mercer et al., 2007).

Two types of balloons were launched during the campaign (see Rabier et al., 2012): (i) driftsondes carrying dropsondes released on demand inside the polar vortex and (ii) stratospheric zero-pressure balloons following a given air mass to document stratospheric dynamics and ozone depletion. These balloons were equipped with radiosondes with electrochemical cell (ECC) ozonesondes to measure ozone during their ascent. Only the latter are used in this study and are called ozonesondes hereafter.

Ozone is one of the key species measured by the IASI mission and is the focus of this paper. Previous studies (e.g. Dufour et al., 2012) have shown that ozone products retrieved from IASI spectra are reliable, although there is still room for improvements, both for accuracy as well as for characterizing the profile data. This study presents comparisons between ozone profiles retrieved from IASI and measured with the ozonesondes onboard zero-pressure plastic balloons during the campaign. This paper is organized as follows: Sect. 2 gives a description of IASI and ozonesonde data; Sect. 3 presents and explains the validation methodology to compare IASI and ozonesonde profiles; in Sect. 4 the results are presented and discussed, and Sect. 5 summarizes the findings of this study.

\section{Data}

\subsection{Satellite observations}

IASI is a long-term mission dedicated to atmospheric sounding using the thermal infrared absorption of the earthatmosphere system. The nadir radiances are collected and distributed in near real time to operational weather forecasting centers (Hilton et al., 2012; Collard and McNally, 2009) as well as for the monitoring of atmospheric composition changes (Clerbaux et al., 2009). IASI is a Fourier transform spectrometer on board the MetOp-A polar-orbiting satellite providing data on each location at least twice a day since June 2007. Due to polar orbits of MetOp, and its scan across the orbit, IASI data have high spatial and temporal resolutions. As the spectrometer measures the thermal infrared spectral range, it provides day and night measurements all over the year (see Clerbaux et al., 2009, for additional information).

Ozone profiles are retrieved in near real time and globally twice daily using an optimal estimation approach, implemented in the Fast Optimal Retrievals on Layers for IASI (FORLI) software (Hurtmans et al., 2012). FORLI-O3 inputs include the following: (i) the spectral radiances extracted

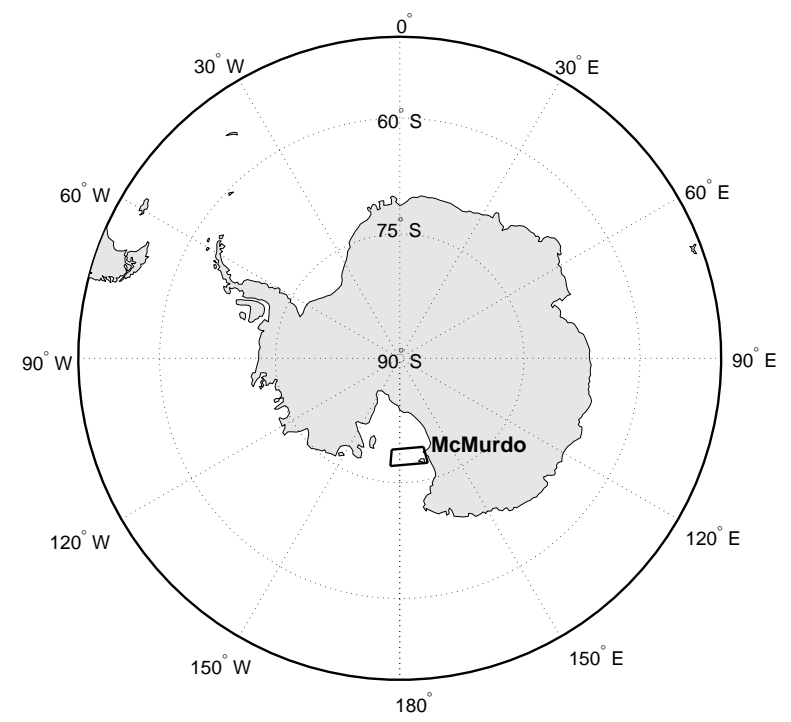

Fig. 1. The McMurdo Station, Antarctica, is located on the southern tip of Ross Island. The black box indicates the longitude/latitude span in which the sonde profiles plotted in Fig. 3 were launched.

from IASI L1C data; (ii) cloud cover, temperature and humidity profiles selected from IASI L2 records, and provided by the European Organisation for the Exploitation of Meteorological Satellites (Eumetsat) (e.g. August et al., 2012). Version 20100815 of FORLI was used for this study. The algorithm uses the IASI $10 \mu \mathrm{m}$ spectral region and 2 to 4 independent pieces of information are retrieved, depending on the location and on the season. It was designed to allow the fast delivery of a global near real time product from the about 1.3 million IASI observations per day. Applications range from the study and the monitoring of the stratospheric ozone hole to tropospheric chemistry and air quality (e.g. Scannell et al., 2012; Parrington et al., 2012; Wespes et al., 2012). Ozone retrievals are performed in the $1025-1075 \mathrm{~cm}^{-1}$ spectral range, in order to minimize the computation time and avoid interferences with water vapour lines. The profiles are retrieved in 39 fair spaced layers of $1 \mathrm{~km}$ thickness, with an extra layer from $39 \mathrm{~km}$ to the top of the atmosphere. The FORLI-O3 products have been validated with different ground-based, aircraft, and satellite data (Scannell et al., 2012; Anton et al., 2011; Pommier et al., 2012). Along with the retrieved profiles, error covariance and averaging kernel (AK) matrices are also provided. The latter are essential to quantify the vertical sensitivity of the retrieved profiles (Fig. 2). The AKs are function of several factors such as surface properties, temperature profile, atmospheric composition and thermal contrast. The latter is defined as the difference between the surface temperature and the temperature of the boundary layer. Previous studies have shown that for IASI the sensitivity towards the surface highly depends on thermal contrast (Clerbaux et al., 2009), and that at high latitudes the information content of the retrieved profile is limited by the low temperatures (Pommier et al., 2012). 


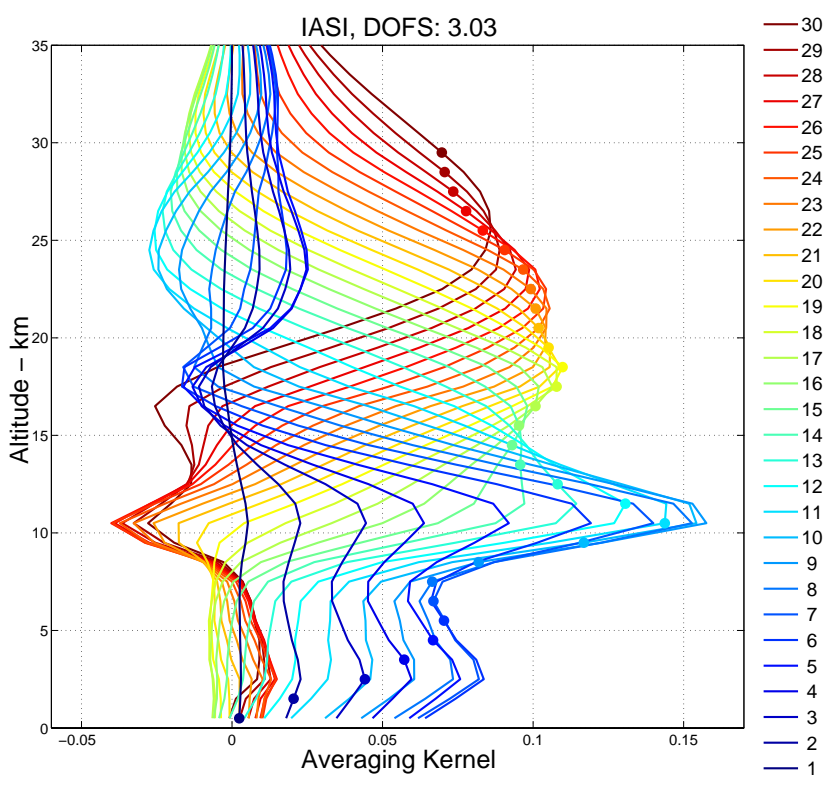

Fig. 2. Typical averaging kernel matrices and DOFs of ozone profile provided by IASI. The figure shows an example observed on 16 September 2010 over McMurdo. Each coloured line corresponds to the altitude indicated by the coloured dot.

\subsection{Sounding balloons/Concordiasi campaign in 2010}

Three field experiments were conducted, in Antarctica, as part of the Concordiasi campaign. Two of them were during the austral spring 2008 and 2009 and a third one, which is the focus of this paper, was in austral spring 2010. These measurements were aimed at documenting three highly interrelated topics: (i) the depletion of the stratospheric ozone layer, (ii) the ozone layer seasonal evolution, and (iii) stratospheric dynamics. In this study, profiles measured by ozonesondes during the field campaign are used. These are carried with 20 zero-pressure balloons performing a single ascent. The balloons carried ENSCI (Environmental Science Corporation) ozonesondes interfaced to either Vaisala or iMet radiosondes to measure ozone concentration along their paths. The ECCs used $0.5 \%$ KI-buffered solutions to sense ozone. For more technical details, the readers should refer to Mercer et al. (2007).

In Fig. 3, trajectories of eight balloons equipped with GPS receivers are presented along with ozone concentrations measured during the flights. In Fig. 1, the black box east of McMurdo identifies the region including all the balloon trajectories shown in Fig. 3. Some of the ozonesondes were equipped with GPS receivers, which allowed obtaining a better collocation and thus made comparison more accurate. Ozone mixing ratio is measured every $5 \mathrm{~s}$ during balloon flight, which lasts between 1 and $3 \mathrm{~h}$. The shortest sample contained around 850 measurements while the longest contained around 2000 measurements (the difference is due to differences in balloon ascent rate). Table 1 lists all the

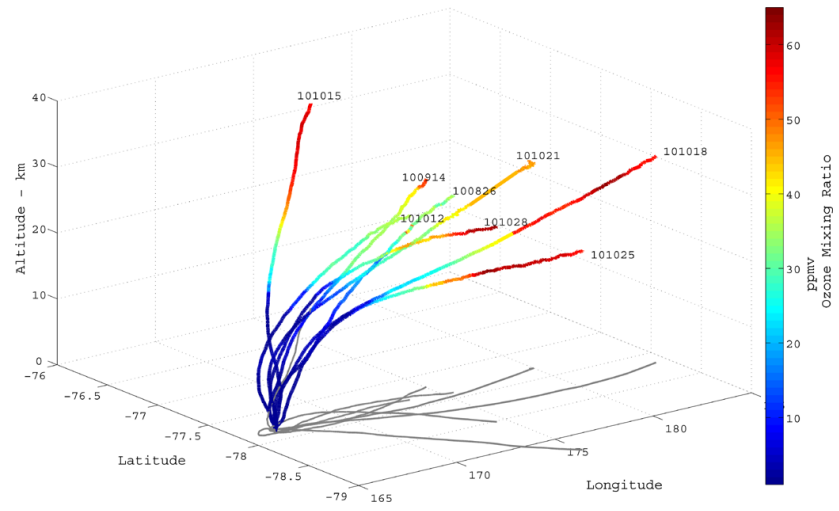

Fig. 3. Ozone profiles measured by zero-pressure balloons at McMurdo during the 2010 Concordiasi campaign. The figure presents the flight paths of the 8 balloons equipped with GPS receivers. Grey lines display the shadows of the trajectories. Each profile is named by its date ("yymmdd") at the top of the profile, and ozone units are given in ppmv. The black square in Fig. 1 identifies the entire latitude/longitude region covered by the sondes.

observations that were used in the framework of this study. It also provides supplementary information such as altitude and the collocation criteria used. The number of profiles corresponds to the number of IASI profiles which are at the smallest distance of the balloon path for comparison with ozonesonde profiles. The underlying assumption of this selection is that the closer to the trajectory, the more likely ozonesondes and IASI profiles sound the same air parcel. If the balloon was equipped with a GPS receiver, all IASI profiles which were along the GPS path were used. If there was no GPS receiver, the collocation criterion was a radius around McMurdo where the IASI profiles were selected. Last column of the table gives the time interval between the middle of the balloon flight and the time when the satellite passed above the site. The distance between the selected IASI profiles and the balloons ranges from 5 to $100 \mathrm{~km}$ (average: $15 \mathrm{~km}$ ), and the temporal coincidence is around $3 \mathrm{~h}$ (minimum: $30 \mathrm{~min}$, maximum: $8 \mathrm{~h}$ ).

According to Kuttippurath et al. (2010), the edge of the vortex varies between -30 and -45 potential vorticity units (PVUs) at $475 \mathrm{~K}$ during the August-November period. Figure 4 shows the -30 and -45 PVU boundaries of the vortex at $475 \mathrm{~K}$, using the ECMWF operational analysed potential vorticity (PV) field for several example comparisons. In fact all of the ozonesondes were flown within the polar vortex since that was a criterion for the measurements. This guarantees that the comparisons are made under conditions with a low ozone spatial gradient, reducing the risk of a poor sampling.

The fact that the balloon launches at McMurdo all occur inside the vortex guarantees stability of ozone profiles and makes the comparisons more useful. 


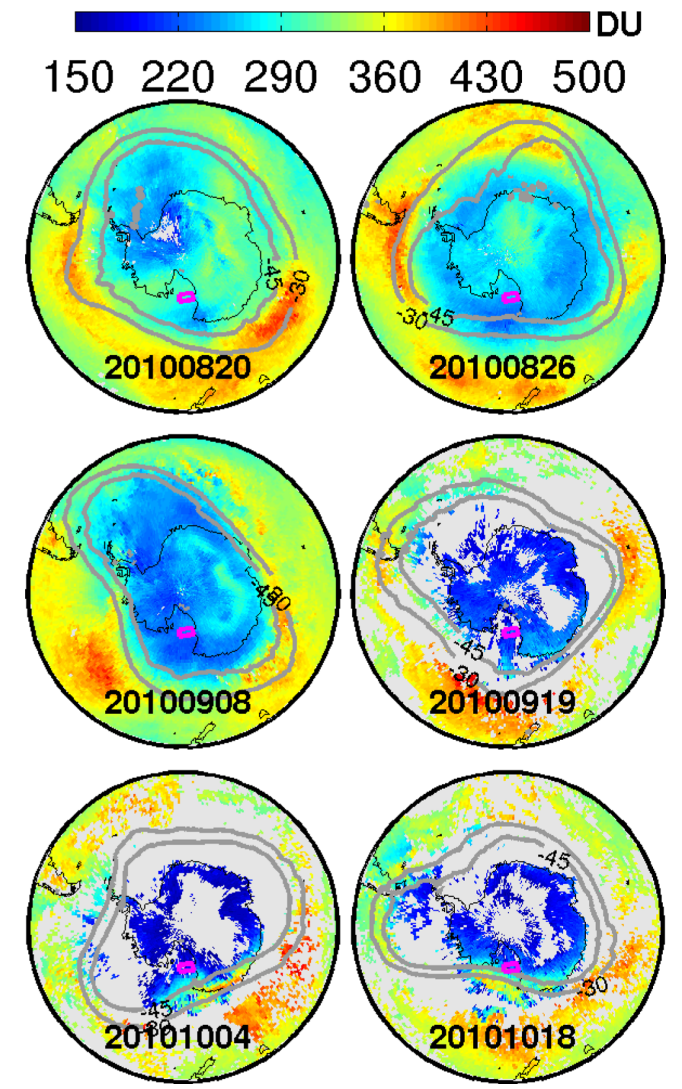

Fig. 4. The status of the vortex and position of McMurdo Station during selected days of the Concordiasi campaign. Ozone total columns retrieved from IASI measurements are in the background. The overlaid grey lines represent -30 and -45 PVU, the approximate boundaries of the vortex. The station remained inside the vortex during the campaign period. Starting from 15 September, the number of IASI data around McMurdo has strongly decreased due to a major change in the Eumetsat temperature retrieval processing. This explains the missing values in white. A dedicated processing was undertaken in the framework of this study to allow for more data in the McMurdo area.

\section{Validation methodology}

The IASI-retrieved quantity is not a real concentration profile, but a reflection of the ability of the instrument to discriminate different atmospheric layers. Therefore one cannot directly compare satellite retrieved profiles with highresolution in situ observations (aircraft, sondes, etc.) and model results. To compare the high-resolution ozone profiles measured with the sonde and with IASI profiles, the highresolution profiles are convolved by the IASI AK matrix with the a priori profile, following Eq. (1):

$$
\boldsymbol{X}_{\text {smoothed }}=\mathbf{A}_{\text {iasi }} \boldsymbol{X}_{\text {sonde }}+\left(\mathbf{I}-\mathbf{A}_{\text {iasi }}\right) \boldsymbol{X}_{\text {a,iasi }},
$$

where $\boldsymbol{X}_{\text {smoothed }}$ is the smoothed profile which uses lowresolution measurement characteristics. $\mathbf{A}_{\text {iasi }}$ is the lowresolution AK. $\boldsymbol{X}_{\text {sonde }}$ is the high-resolution profile given
Table 1. Balloon data used in this study. First column presents the month and day the balloon was launched; second column indicates whether the balloon was equipped with a GPS ("0") or not ("X"). Third column gives the bursting altitude of the balloon above sea level. Then the number of IASI profiles considered for each comparison and the collocation criteria are respectively given in the fourth and fifth column. The sixth column gives an approximation of the time interval between the middle of the balloon flight and time when the satellite passed above the site. Letters "a" and "b" respectively stand for "after" and "before" satellite passing.

\begin{tabular}{|c|c|c|c|c|c|}
\hline $\begin{array}{l}\text { Day of } \\
\text { launch }\end{array}$ & GPS & $\begin{array}{r}\text { Altitude } \\
(\mathrm{km})\end{array}$ & $\begin{array}{c}\text { Number } \\
\text { of prof. }\end{array}$ & $\begin{array}{r}\text { Colloc. } \\
\text { crit. }(\mathrm{km})\end{array}$ & $\begin{array}{l}\text { Time } \\
\text { interval }\end{array}$ \\
\hline 20 August & $X$ & 30.23 & 3 & 10 & $02 \mathrm{~h} 00 \min ^{\mathrm{a}}$ \\
\hline 22 August & $X$ & 30.46 & 6 & 100 & $07 \mathrm{~h} 00 \mathrm{~min}^{\mathrm{b}}$ \\
\hline 26 August & $\mathrm{O}$ & 29.82 & 18 & 5 & $02 \mathrm{~h} 30 \mathrm{~min}^{\mathrm{a}}$ \\
\hline 3 September & $X$ & 30.32 & 7 & 10 & $02 \mathrm{~h} 00 \min ^{\mathrm{a}}$ \\
\hline 8 September & $X$ & 31.54 & 7 & 10 & $07 \mathrm{~h} 00 \mathrm{~min}^{\mathrm{b}}$ \\
\hline 10 September & $\mathrm{X}$ & 31.43 & 4 & 10 & $02 \mathrm{~h} 30 \mathrm{~min}^{\mathrm{b}}$ \\
\hline 14 September & $\mathrm{O}$ & 31.54 & 3 & 30 & $00 \mathrm{~h} 30 \mathrm{~min}^{\mathrm{a}}$ \\
\hline 16 September & $\mathrm{X}$ & 32.66 & 4 & 30 & $02 \mathrm{~h} 30 \mathrm{~min}^{\mathrm{b}}$ \\
\hline 19 September & $\mathrm{X}$ & 26.84 & 1 & 10 & $08 \mathrm{~h} 00 \mathrm{~min}^{\mathrm{b}}$ \\
\hline 25 September & $X$ & 32.09 & 4 & 20 & $03 \mathrm{~h} 00 \min ^{\mathrm{a}}$ \\
\hline 27 September & $\mathrm{X}$ & 29.41 & 2 & 20 & $06 \mathrm{~h} 00 \min ^{\mathrm{a}}$ \\
\hline 30 September & $X$ & 33.29 & 5 & 30 & $02 \mathrm{~h} 00 \mathrm{~min}^{\mathrm{b}}$ \\
\hline 4 October & $\mathrm{X}$ & 32.22 & 3 & 30 & $04 \mathrm{~h} 30 \mathrm{~min}^{\mathrm{b}}$ \\
\hline 8 October & $X$ & 34.03 & 3 & 30 & $04 \mathrm{~h} 30 \mathrm{~min}^{\mathrm{b}}$ \\
\hline 12 October & $\mathrm{O}$ & 28.04 & 4 & 5 & $04 \mathrm{~h} 30 \mathrm{~min}^{\mathrm{b}}$ \\
\hline 15 October & $\mathrm{O}$ & 31.01 & 15 & 5 & $03 \mathrm{~h} 30 \mathrm{~min}^{\mathrm{a}}$ \\
\hline 18 October & $\mathrm{O}$ & 31.34 & 5 & 10 & $03 \mathrm{~h} 30 \mathrm{~min}^{\mathrm{b}}$ \\
\hline 21 October & $\mathrm{O}$ & 31.68 & 7 & 5 & $01 \mathrm{~h} 00 \min ^{\mathrm{a}}$ \\
\hline 25 October & $\mathrm{O}$ & 30.26 & 15 & 10 & $02 \mathrm{~h} 30 \mathrm{~min}^{\mathrm{a}}$ \\
\hline 28 October & $\mathrm{O}$ & 29.59 & 12 & 5 & $00 \mathrm{~h} 30 \mathrm{~min}^{\mathrm{b}}$ \\
\hline
\end{tabular}

by the sonde, and $\boldsymbol{X}_{\mathrm{a} \text {,iasi }}$ is the low-resolution a priori profile. The a priori covariance matrix is constructed from the McPeters/Labow/Logan climatology of ozone vertical distribution, which combines long-term satellite limb measurements and measurements from ozonesondes (see McPeters et al., 2007; Hurtmans et al., 2012). If the retrieval was ideal, $\mathbf{A}_{\text {iasi }}$ would tend to $\mathbf{I}$ and the influence of a priori on the retrieved quantity would be zero (see Rodgers and Connor, 2003, for more details).

This smoothing process reduces ozonesonde profile samples from around one measurement every $40 \mathrm{~m}$ to one measurement every kilometer according to altitude dependence given by IASI AK. The resulting smoothed profile is then compared to the IASI profile. Equation (1) can be seen as a linear combination between an a priori profile and the observation, the weight of which is given by the AK. Simultaneously, it allows the projection of high-resolution observation profiles on IASI lower-resolution space. A single a priori profile representative of the standard ozone concentration in Antarctica is used for these retrievals.

The mean relative error between IASI and ozonesonde profiles and its confidence interval are calculated from the individual comparisons estimated via Eq. (2). The relative error is given by 


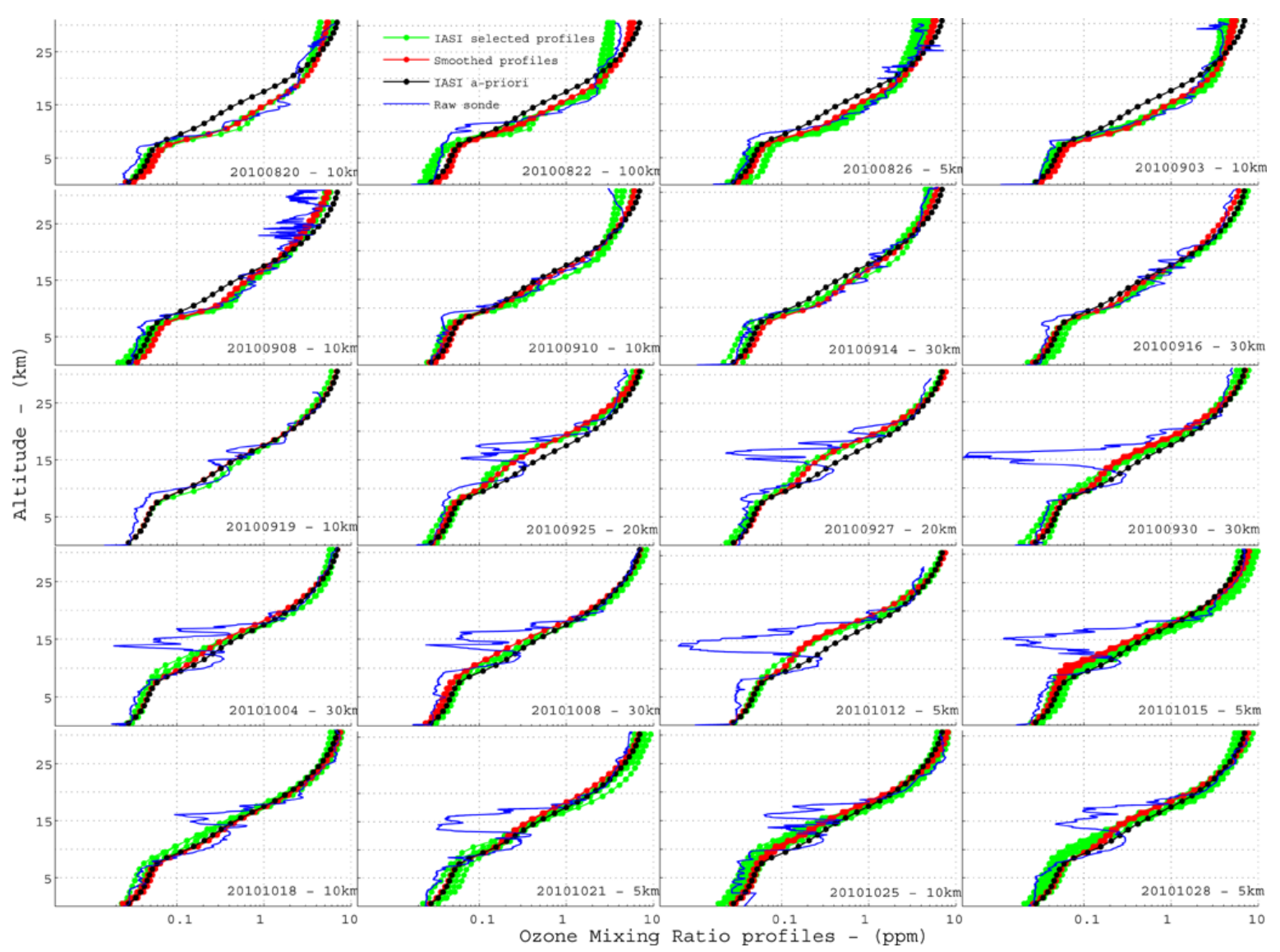

Fig. 5. Comparison between the high-resolution raw ozonesonde profile (blue), the low-resolution smoothed ozonesonde profiles (red) and the low-resolution IASI/MetOp ozone profiles (green). Note that the graphs use logarithmic x-scale. Collocation criteria are given in each plot next to the date.

\section{Results and discussion}

$\Delta \boldsymbol{X}=\left(\boldsymbol{X}_{\text {iasi }}-\boldsymbol{X}_{\text {smoothed }}\right) / \boldsymbol{X}_{\text {smoothed }}$,

where $\boldsymbol{X}_{\text {iasi }}$ is the IASI profile and $\boldsymbol{X}_{\text {smoothed }}$ is the smoothed ozonesonde profile calculated through Eq. (1). This difference is estimated for each ozonesonde observation and each collocated IASI profile. The $95 \%$ confidence interval for this comparison is calculated through the sample mean $\mathbf{E}$ and is given by

$$
\left[\mathbf{E}[\Delta \boldsymbol{X}]-1.6 \frac{\sigma}{\sqrt{n}} ; \mathbf{E}[\Delta \boldsymbol{X}]+1.6 \frac{\sigma}{\sqrt{n}}\right],
$$

where $n$ is the total number of comparisons and $\sigma$ is the variance of the differences. This mean relative error $(\mathbf{E}[\Delta \boldsymbol{X}])$ gives the error made by IASI at each altitude range. The $95 \%$ confidence interval given by Eq. (3) indicates the reliability of the mean and represents the interval which would include the error with a 0.95 probability if the comparison is repeated. In Eq. (3), number 1.6 represents the 97.5 percentile point of the Student's $t$ distribution, which is commonly used to describe the mean of a normally distributed sample with variance to be estimated (see Frontier et al., 2007, for additional details on confidence intervals).
Figure 5 shows the overall comparisons between IASI satellite data and 20 ozonesonde measurements during the Concordiasi campaign. The blue lines represent the raw observed profiles measured by ozonesondes ( $\boldsymbol{X}_{\text {sonde }}$ in Eq. 1). IASI profiles ( $\boldsymbol{X}_{\text {iasi }}$ in Eq. 2 ) are presented in subplots by green lines. Black lines are the constant IASI a priori profiles $\left(\boldsymbol{X}_{\mathrm{a}, \text { iasi }}\right.$ in Eq. 1). Finally, red lines represent the smoothed profiles calculated from $\boldsymbol{X}_{\text {smoothed }}$ of Eq. (1).

Each IASI profile is given a specific AK, so Eq. (1) is calculated for each IASI profile. The relevant comparison in Fig. 5 is to be done between red (smoothed ozonesonde profile) and green lines (IASI profile). The smaller the distance, the better the match is between the IASI profiles and the smoothed ozonesonde profile. For example, in Fig. 5, the balloon launched on 14 September (2nd row, 3rd column) was equipped with a GPS receiver and there were four IASI profiles in a perimeter of $30 \mathrm{~km}$ along its path. The agreement between IASI profiles (green lines) and the smoothed sonde profiles (red lines) is much closer than, for example, for the 22 August balloon, which was not equipped with GPS 
receiver and for which the closest IASI profiles were around $100 \mathrm{~km}$ away from McMurdo.

In Fig. 6a, all observations are considered. The black lines represent the mean relative error $(\mathbf{E}[\Delta \boldsymbol{X}])$ and the $95 \%$ confidence interval (Eq. 3) considering all comparisons between ozonesondes and IASI profiles. The red lines show similar results but only considering comparisons with the GPSequipped ozonesondes. This average difference is calculated as the mean of the relative error between IASI profiles and the smoothed ozonesonde profiles (Eq. 2). Note that the width of the confidence interval is nearly constant with altitude and equals $\approx 1.5 \%$ for both errors.

The average relative difference remains between $-10 \%$ and $+26 \%$, depending on altitude. In the troposphere, between $0 \mathrm{~km}$ and $10 \mathrm{~km}$, IASI data show a particularly good agreement (i.e. relative difference remains between $-7 \%$ and $0 \%$ ). Comparisons based on ozonesondes equipped with GPS significantly improve the agreement, with an error less than $5 \%$ in the troposphere. The improvement near the surface comes from a better selection of IASI profiles, where collocations were improved by the available GPS data. Moreover, the collocation of profiles is carried out based on the matching of the two soundings at the surface altitude, which also favours a better comparison at the lower part of the profiles.

It is worth noting that, as mentioned before, the vertical sensitivity decreases with latitude due to lower information content in the signal (associated with low surface temperature), and hence for an observation with low thermal contrast (e.g. above sea water) the retrieved profile between 0 and $10 \mathrm{~km}$ is contaminated by the a priori information. When the thermal contrast is significant (it can easily reach $-10 \mathrm{~K}$ above icy surface), there is some relevant information (e.g. see Fig. 2) retrieved. As the tropospheric ozone content does not vary much at the McMurdo location, the average agreement is good, partly because it remains close to the a priori profile.

However, between $10 \mathrm{~km}$ and $25 \mathrm{~km}$ (corresponding to the lower stratosphere), IASI tends to overestimate the observations up to $26 \%$. In the lower stratosphere, this bias confirms the bias estimated by previous works (e.g. Scannell et al., 2012) and in other regions such as Iberian Peninsula (Anton et al., 2011), at midlatitudes and in the tropics (Dufour et al., 2012). Dufour et al. (2012) showed that three independent IASI ozone retrieval codes tend to overestimate ozone in the upper troposphere/lower stratosphere region in the midlatitudes and the tropics.

A large ozone loss $(\approx 0.3-0.5 \mathrm{ppm}$ ozone loss for each altitude) can be seen on the ozonesonde profiles (blue lines) measured between $10 \mathrm{~km}$ and $20 \mathrm{~km}$ from 19 September (Fig. 5). To verify whether the overestimation is induced by this gradient, Fig. $6 \mathrm{~b}$ compares the profiles measured before and after 19 September. This corresponds to the time when ozone depletion is observed by IASI in ozone mixing ratio profiles. Soon after it is measured at McMurdo during the

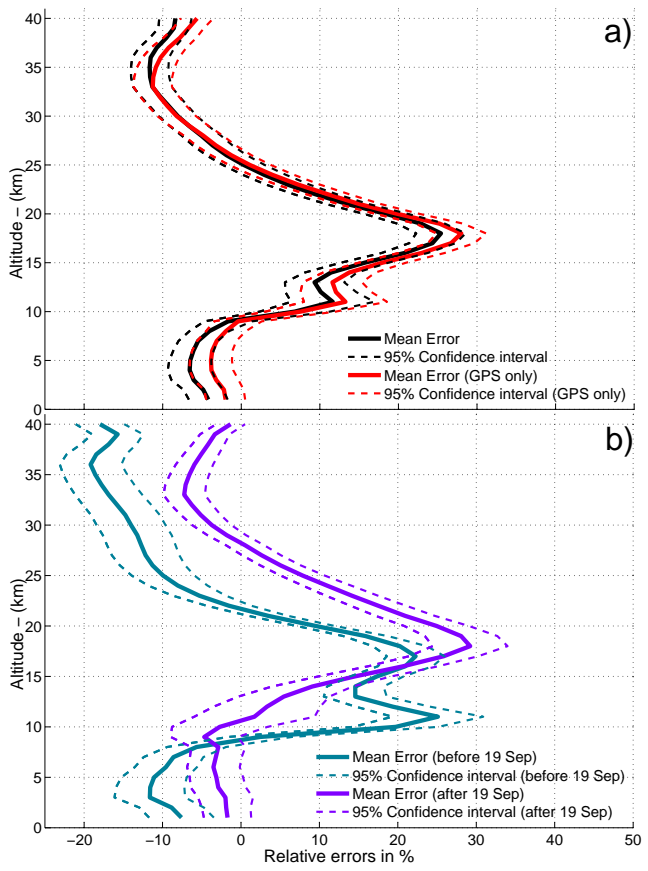

Fig. 6. (a) The average relative difference computed between IASI and radiosonde ozone profile measurements. It is the average of 20 comparisons, where the relative error is calculated as the difference between IASI profile and the smoothed balloon profile divided by the smoothed profile at each altitude. Black lines represent the mean and confidence interval of overall comparisons, whereas red lines take into account only comparisons of GPS-equipped ozonesondes. (b) Blue lines represent the comparisons of profiles observed before 19 September, whereas violet lines represent profiles observed after 19 September (when ozone loss was clearly observed in the mixing ratio profiles).

first week of September (Fig. 5). The figure illustrates that the overestimation of IASI between $10 \mathrm{~km}$ and $25 \mathrm{~km}$ is not due to ozone depletion as it is observed both before and during the depletion process. The different vertical structures of both lines are explained by the increasing variability of the signal between $15 \mathrm{~km}$ and $20 \mathrm{~km}$ due to ozone loss process (Fig. 5). Then, at this altitude range, the overestimation of IASI ozone does not depend on the distribution of ozone, but should be considered as systemic to IASI retrieval process. At this altitude range, the use of GPS receivers does not reduce the error. Between $15 \mathrm{~km}$ and $20 \mathrm{~km}$, the error seems to increase when only the GPS sondes are used, but the difference with the overall comparisons is not significantly high (i.e. the GPS-only error is included in the confidence interval of the overall comparisons and vice versa).

In the upper part of the profile, which roughly corresponds to the middle stratosphere (i.e. between $25 \mathrm{~km}$ and $40 \mathrm{~km}$ ), the discrepancies decrease again (between -10 and $-5 \%$ ). This bias at the top of profiles is mainly due to the decreasing sensitivity of IASI (see Fig. 2). Boxe et al. (2010) performed a similar study with Tropospheric Emission Spectrometer 
(TES) satellite, also a thermal infrared nadir instrument, during the Arctic Research on the Composition of the Troposphere from Aircraft and Satellites (ARCTAS) field mission between April and July 2008 in northern latitudes (between $44^{\circ}$ and $71^{\circ}$ ). They show similar biases in the distribution of ozone in the troposphere, UT/LS and middle stratosphere region. At this altitude range, GPS-equipped radiosondes do not show a significant improvement.

\section{Conclusions}

Accurate measurements of ozone profiles using satellite instruments remain difficult over the poles, in particular when a decrease of ozone is observed (during September-November period in Southern Hemisphere). For thermal infrared remote sensors such as IASI, the difficulty is amplified by the low surface temperature. In this work, 20 ozonesonde profiles are under study; they were observed during the Concordiasi balloon campaign which took place at McMurdo Station, Antarctica, in 2010 to compare with FORLI-O3 IASIretrieved ozone profiles. Some of the launched balloons were equipped with GPS receivers. When available, the GPS data are used to select IASI profiles along the sonde path, which makes the comparisons more accurate as the closest IASI profiles are selected. The study shows that the smaller the distance, the better the match between the IASI profiles and the smoothed ozonesonde profile. Ozonesonde profiles were first smoothed with AKs to be compared with IASI observations. A good agreement is found between the two datasets even with the reduced sensitivity associated with high latitude (low temperature) and ice surface (emissivity issues). Red lines in Fig. 6a show that a relative difference between -10 and $0 \%$ was found in the troposphere (between surface and $10 \mathrm{~km}$ ) and also between $25 \mathrm{~km}$ and $40 \mathrm{~km}$, provided the data are well collocated (sondes equipped with GPS).

The overestimation of ozone in the $10-25 \mathrm{~km}$ range has already been highlighted in previous studies and with other instruments (e.g. TES as described in Boxe et al., 2010). The positive bias was found to occur both for ozone depleting and standard conditions. Consequently, IASI achieves measurement of ozone depletion events as well as measurement of ozone distribution during non-depletion events. Previous studies showed similar biases at different latitudes (e.g. Boxe et al., 2010; Anton et al., 2011), and this study illustrates that their finding remains valid at southern latitudes. This work should trigger a detailed study of why a systematic bias is observed not only in the lower stratosphere, at midlatitudes and in the tropics, but also over Antarctica. It might be due to spectroscopic issues (a UV-TIR bias was pointed in previous studies), to inadequacy of a priori covariance matrix, or to any other reason yet to be identified.
Acknowledgements. The IASI mission is a joint mission of Eumetsat and the Centre National d'Études Spatiales (CNES, France). This work was undertaken under the auspices of the O3M SAF project of the Eumetsat. The IASI L1 data are distributed in near real time by Eumetsat through the EUMETCast system distribution. Specials thanks to Joerg Schultz and Roger Huckle (Eumetsat) who generated missing L2 temperature data for us. The authors acknowledge the French Ether atmospheric database (http://ether.ipsl.jussieu.fr) for providing the IASI L1C data and L2 data. The French scientists are grateful to CNES for scientific collaboration and financial support. Concordiasi was built by an international scientific group and is currently supported by the following agencies: Météo-France, CNES, IPEV, PNRA, CNRS/INSU, NSF, UCAR, University of Wyoming, Purdue University, University of Colorado, and ECMWF. The NSF is thanked for its support at the McMurdo base. Ozonesonde measurements were supported by the NSF under OPP grant \# 0839124, which was separate from the Concordiasi project. Concordiasi is part of the IPY-THORPEX cluster within the International Polar Year effort. P. F. Coheur is Research Associate (Chercheur Qualifié) with F.R.S.-FNRS. The research in Belgium was funded by the F.R.S.-FNRS, the Belgian State Federal Office for Scientific, Technical and Cultural Affairs and the European Space Agency (ESA-Prodex arrangements C-4000103226). Financial support by the "Actions de Recherche Concertées" (Communauté Francaise de Belgique) is also acknowledged. The coauthors are grateful to INSU for publication support.

Edited by: F. Boersma

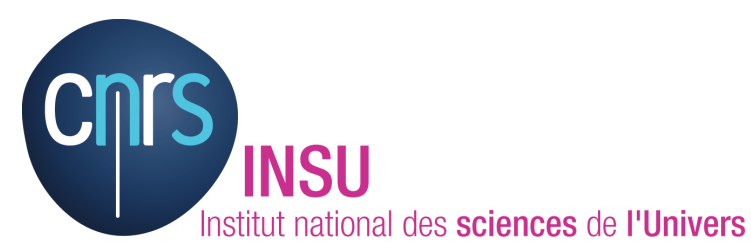

The publication of this article is financed by CNRS-INSU.

\section{References}

Anton, M. D., Loyola, D., Clerbaux, C., López, M., Vilaplana, J. M., Bañón, M., Hadji-Lazaro, J., Valks, P., Hao, N., Zimmer, W., Coheur, P.-F., Hurtmans, D., and Alados-Arboledas, L.: Validation of the Metop-A total ozone data from GOME-2 and IASI using reference ground-based measurements at the Iberian Peninsula, Remote Sens. Environ., 115, 1380-1386, 2011.

August, T., Klaes, D., Schlüssel, P., Hultberg, T., Crapeau, M., Arriaga, A., O'Carroll, A., Coppens, D., Munro, R., and Calbet, X.: IASI on Metop-A: operational level 2 retrievals after five years in orbit, J. Quant. Spectrosc. Ra., 113, 1340-1371, doi:10.1016/j.jqsrt.2012.02.028, 2012.

Boxe, C. S., Worden, J. R., Bowman, K. W., Kulawik, S. S., Neu, J. L., Ford, W. C., Osterman, G. B., Herman, R. L., Eldering, A., Tarasick, D. W., Thompson, A. M., Doughty, D. C., Hoffmann, M. R., and Oltmans, S. J.: Validation of northern latitude Tropospheric Emission Spectrometer stare ozone profiles with ARC-IONS sondes during ARCTAS: sensitivity, bias and error 
analysis, Atmos. Chem. Phys., 10, 9901-9914, doi:10.5194/acp10-9901-2010, 2010.

Clerbaux, C., Boynard, A., Clarisse, L., George, M., HadjiLazaro, J., Herbin, H., Hurtmans, D., Pommier, M., Razavi, A., Turquety, S., Wespes, C., and Coheur, P.-F.: Monitoring of atmospheric composition using the thermal infrared IASI/MetOp sounder, Atmos. Chem. Phys., 9, 6041-6054, doi:10.5194/acp9-6041-2009, 2009.

Collard, A. and McNally, A. P.: The assimilation of Infrared Atmospheric Sounding Interferometer radiances at ECMWF, Q. J. Roy. Meteorol. Soc., 135, 1044-1058, doi:10.1002/qj.410, 2009.

Dufour, G., Eremenko, M., Griesfeller, A., Barret, B., LeFlochmoën, E., Clerbaux, C., Hadji-Lazaro, J., Coheur, P.-F., and Hurtmans, D.: Validation of three different scientific ozone products retrieved from IASI spectra using ozonesondes, Atmos. Meas. Tech., 5, 611-630, doi:10.5194/amt-5-611-2012, 2012.

Frontier, S., Davoult, D., Gentilhomme, V., and Lagadeuc, Y.: Statistique pour les sciences de la vie et de l'environnement, Dunod, Paris, France, Sciences Sup Edn., 2007.

Hilton, F., August, T., Barnet, C., Bouchard, A., Camy-Peyret, C., Clarisse, L., Clerbaux, C., Coheur, P.-F., Collard, A., Crevoisier, C., Dufour, G., Edwards, D., Faijan, F., Fourrié, N., Gambacorta, A., Gauguin, S., Guidard, V., Hurtmans, D., Illingworth, S., Jacquinet-Husson, N., Kerzenmacher, T., Klaes, D., Lavanant, L., Masiello, G., Matricardi, M., McNally, T., Newman, S., Pavelin, E., Péquignot, E., Phulpin, T., Remedios, J., Schlüssel, P., Serio, C., Strow, L., Taylor, J., Tobin, D., Uspensky, A., and Zhou, D.: Hyperspectral earth observation from IASI: five years of accomplishments, B. Am. Meteorol. Soc., 93, 347-370, doi:10.1175/BAMS-D-11-00027.1, 2012.

Hurtmans, D., Coheur, P.-F., Wespes, C., Clarisse, L., Scharf, O., Clerbaux, C., Hadji-Lazaro, J., George, M., and Turquety, S.: FORLI radiative transfer and retrieval code for IASI, J. Quant. Spectrosc. Ra., 113, 1391-1408, doi:10.1016/j.jqsrt.2012.02.036, 2012.

Kuttippurath, J., Goutail, F., Pommereau, J.-P., Lefèvre, F., Roscoe, H. K., Pazmiño, A., Feng, W., Chipperfield, M. P., and Godin-Beekmann, S.: Estimation of Antarctic ozone loss from ground-based total column measurements, Atmos. Chem. Phys., 10, 6569-6581, doi:10.5194/acp-10-6569-2010, 2010.

McPeters, R., Labow, G., and Logan, J.: Ozone climatological profiles for satellite retrieval algorithms, J. Geophys. Res., 112, D05308, doi:10.1029/2005JD006823, 2007.

Mercer, J. L., Kröger, C., Nardi, B., Johnson, B. J., Chipperfield, M. P., Wood, S. W., Nichol, S. E., Santee, M. L., and Deshler, T.: Comparison of measured and modeled ozone above McMurdo Station, Antarctica, 1989-2003, during austral winter/spring, J. Geophys. Res., 112, D19307, doi:10.1029/2006JD007982, 2007.

Newman, P. A., Oman, L. D., Douglass, A. R., Fleming, E. L., Frith, S. M., Hurwitz, M. M., Kawa, S. R., Jackman, C. H., Krotkov, N. A., Nash, E. R., Nielsen, J. E., Pawson, S., Stolarski, R. S., and Velders, G. J. M.: What would have happened to the ozone layer if chlorofluorocarbons (CFCs) had not been regulated?, Atmos. Chem. Phys., 9, 2113-2128, doi:10.5194/acp-92113-2009, 2009.
Parrington, M., Palmer, P. I., Henze, D. K., Tarasick, D. W., Hyer, E. J., Owen, R. C., Helmig, D., Clerbaux, C., Bowman, K. W., Deeter, M. N., Barratt, E. M., Coheur, P.-F., Hurtmans, D., Jiang, Z., George, M., and Worden, J. R.: The influence of boreal biomass burning emissions on the distribution of tropospheric ozone over North America and the North Atlantic during 2010, Atmos. Chem. Phys., 12, 2077-2098, doi:10.5194/acp-122077-2012, 2012.

Pommier, M., Clerbaux, C., Law, K. S., Ancellet, G., Bernath, P., Coheur, P.-F., Hadji-Lazaro, J., Hurtmans, D., Nédélec, P., Paris, J.-D., Ravetta, F., Ryerson, T. B., Schlager, H., and Weinheimer, A. J.: Analysis of IASI tropospheric $\mathrm{O}_{3}$ data over the Arctic during POLARCAT campaigns in 2008, Atmos. Chem. Phys., 12, 7371-7389, doi:10.5194/acp-12-7371-2012, 2012.

Rabier, F., Bouchard, A., Brun, E., Doerenbecher, A., Guedj, S., Guidard, V., Karbou, F., Peuch, V.-H., El Amraoui, L., Puech, D., Genthon, C., Picard, G., Town, M., Hertzog, A., Vial, F., Cocquerez, P., Cohn, S., Hock, T., Fox, J., Cole, H., Parsons, D., Powers, J., Romberg, K., Van Andel, J., Deshler, T., Mercer, J., Haase, J., Avallone, L., Kalnajs, L., Mechoso, C., Tangborn, A., Pellegrini, A., Frenot, Y., Thepaut, J.-N., McNally, A., Balsamo, G., and Steinle, P.: The Concordiasi project in Antarctica, B. Am. Meteorol. Soc., 91, 69-86, doi:10.1175/2009BAMS2764.1, 2012.

Rodgers, C. D. and Connor, B. J.: Intercomparison of remote sounding instruments, J. Geophys. Res., 108, 4116, doi:10.1029/2002JD002299, 2003.

Scannell, C., Hurtmans, D., Boynard, A., Hadji-Lazaro, J., George, M., Delcloo, A., Tuinder, O., Coheur, P.-F., and Clerbaux, C.: Antarctic ozone hole as observed by IASI/MetOp for 2008-2010, Atmos. Meas. Tech., 5, 123-139, doi:10.5194/amt5-123-2012, 2012.

Vincensini, A., Bouchard, A., Rabier, F., Guidard, V., Fourrié, N., and Traullé, O.: IASI Retrievals Over Concordia Within the Framework of the Concordiasi Program in Antarctica, IEEE T. Geosci. Remote, 50, 2923-2933, doi:10.1109/TGRS.2011.2177467, 2012.

Wespes, C., Emmons, L., Edwards, D. P., Hannigan, J., Hurtmans, D., Saunois, M., Coheur, P.-F., Clerbaux, C., Coffey, M. T., Batchelor, R. L., Lindenmaier, R., Strong, K., Weinheimer, A. J., Nowak, J. B., Ryerson, T. B., Crounse, J. D., and Wennberg, P. O.: Analysis of ozone and nitric acid in spring and summer Arctic pollution using aircraft, ground-based, satellite observations and MOZART-4 model: source attribution and partitioning, Atmos. Chem. Phys., 12, 237-259, doi:10.5194/acp12-237-2012, 2012.

WMO: Scientific Assessment of Ozone Depletion: 2010, Global Ozone Research and Monitoring Project, Report No. 52, Geneva, 2011. 